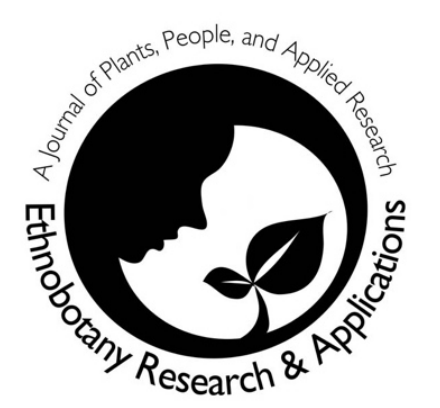

\title{
Ethnobotanical uses and distribution status of Arbutus unedo in Morocco
}

\author{
Faida Rahima, Aabdousse Jamal, Boulli Abdelali, Bouda \\ Said, Wahid Nadya
}

\section{Databases and Inventories}

\begin{abstract}
Background: Arbutus is a fruit tree with high ornamental, environmental, economic and medical value, because of the properties attributed to different biological parts. Given this interest, the present study is interested in describing the distribution, ecology and ethnobotanical status of natural populations.
\end{abstract}

Methods: The range of this species has been largely prospected and explored to locate their natural populations and describe their distribution and conservation. For ethnobotanical uses of Arbutus in Morocco, we compiled available data from literature.

Results: The prospection of the Arbutus natural distribution areas in Morocco has shown that the species is growing in different biogeographical regions. Moreover, of its ecological plasticity and phyto-association, its resistance to mutilations and its great dynamism, it is very present in the everyday uses of foresters, farmers and rural populations. The international bibliographic analysis shows that the different biological parts of Arbutus, especially fruits, have been widely used by herbalists. The related literature is generally in line with the medicinal use of the plant by Moroccan inhabitants. On the other hand, the consumption and the industrial valorization of the fruits of Arbutus are very limited in Morocco in comparison with those on the international scale.

Conclusions: It is imperative to sensitize the local population and landlocked Douars on the knowledge of the valorization of the fruit of this species, and how to develop the marketing, the conservation and the transformation of fruits and by-products, and the production of new medicines and wellness products.

Key words: Arbutus unedo L., ethnobotanical uses, prospection, ecology, Arbutus fruit.

\section{Résumé}

Contexte: L'arbousier est un arbre fruitier à haute valeur, environnementale, économique et médicale, en raison de ces propriétés attribuées aux différentes parties biologiques. Compte tenu de cet intérêt, la présente étude s'intéresse à la description de la répartition, écologie et du statut ethnobotanique des populations naturelles de cette espèce.

Méthodes: L'aire de répartition de cette espèce a été largement prospectée et explorée afin de localiser ses populations naturelles et de décrire leur répartition et leur conservation. Pour les utilisations ethnobotaniques d'Arbutus au Maroc, nous avons rassemblé les données disponibles provenant de la littérature.

\section{Correspondence}

Faida Rahima ${ }^{1,2}$, Aabdousse Jamal 1, Boulli Abdelali ${ }^{1}$, Bouda Said ${ }^{2}$, Wahid Nadya ${ }^{1^{*}}$

${ }^{1}$ Team of Ecology and Sustainable Development, Department of Life Sciences, Faculty of Science and Technology, Sultan Moulay Slimane University, BP 523, 23000 Béni Mellal, Morocco

2 Laboratory of Biotechnology an and Valorization of Natural plant genetic Resources, Department of Life Sciences, Faculty of Science and Technology, Sultan Moulay Slimane University, BP 523, 23000 Béni Mellal, Morocco

*Corresponding author: email:wahid2na@yahoo.fr or n.wahid@usms.ma

\section{Ethnobotany Research \& Applications}

18:30 (2019)

Résultats: La prospection des zones de distribution naturelle d'Arbutus au Maroc a montré que l'espèce se développe dans différentes régions biogéographiques. De plus, de par sa plasticité écologique et sa phyto-association, sa résistance 
aux mutilations et son grand dynamisme, il est très présent dans les utilisations quotidiennes des forestiers, des agriculteurs et des populations rurales. L'analyse bibliographique internationale montre que les différentes parties biologiques d'Arbutus, notamment les fruits, ont été largement utilisées par les herboristes. La littérature connexe est généralement en ligne avec l'utilisation médicinale de la plante par les habitants marocains. En revanche, la consommation et la valorisation industrielle des fruits d'Arbutus sont très limitées au Maroc par rapport à celles à l'échelle internationale.

Conclusions: II est impératif de sensibiliser la population locale et les Douars à la connaissance de la valorisation du fruit de cette espèce et de la manière de développer la commercialisation, la conservation et la transformation des fruits et des produits dérivés.

Mots clés: Arbutus unedo L., usages ethnobotaniques, prospection, écologie, fruit d'arbousier.

\section{Background}

The Arbutus (Arbutus unedo L.) is a fruit tree belonging to the family Ericaceae and often called strawberry tree. It is found in western, central and southern Europe, northeastern Africa, the Canary Islands and western Asia. It can also be found distributed in countries in North America, and on the Atlantic coast such as Ireland and Macaronesia (Canary Islands) (Abbas 2015, Celikel et al. 2008, Rodriguez 2011). In the Mediterranean, it is present in Portugal, Spain, France, Italy, Morocco, Albania, Croatia, Bosnia, Montenegro, Grec, Turkey and the Mediterranean islands (Pedro 1994, Rodriguez 2011, Torres et al. 2002). It's a tree that grows in acidic and calcareous soils and can reach up to 12 meters and can grow in rocky areas (Krussmann 1982, Rodriga de Sà 2010). As a Mediterranean plant, it has the ability to regenerate after forest fires (Konstantinidis et al. 2006). Generally, it has a height growth of shrubs ranging from about 5 meters to 12 meters, with branches that grow from the chest from 0.5 meters above the ground (Rodriga de Sà 2010, Seidemann 1995). Also known as the persistent leaf plant, the Arbutus canopy is rounded with elliptically shaped persistent leaves that assume a dark green color similar to that of cork, with a waxy glow on the upper surface. The flowers of this tree, white or slightly pink, are very decorative which makes it ornamental. Flowers are still considered to be of great importance to the ecosystem because they are a source of nectar for bees (Floris et al. 1992, Soro \& Paxton 1999). All these biological properties make the Arbutus tree of great ecological and ornamental importance. Also, the Arbutus plant is now considered a source of therapeutic agents in medicine (Pawlowska et al. 2006, Silva-E-Alarcão et al. 2001). These properties come mainly from its chemical composition rich in secondary compounds with antioxidant properties, namely: phenols, vitamins $C$ and $E$, carotenoids and organic acids (Fiorentino et al. 2007, Kivçak et al. 2001, Males et al. 2006, Pallauf et al. 2008). Arbutus leaves are used for their antioxidant, astringent, diuretic, antidiarrheal, depurative and more recently used in the treatment of diseases such as hypertension, diabetes and inflammatory problems (Mariotto et al. 2008, Oliveira et al. 2009, Ziyyat \& Boussairi 1998). In addition to its use in traditional medicine, the fruit of the Arbutus tree is highly sought after for its nutritional qualities. It is used for the consumption and production of alcoholic beverages, jams, jellies and marmalades (Pawlowska et al. 2006, Simonetti et al. 2008). Many epidemiological studies have noted that high fruit and vegetable consumption is associated with reduced disease risk (Boubekri 2014, Oliveira et al. 2011). Arbutus berries contain significant amounts of phytochemical compounds, including polyphenols and oligo-minerals, which are micronutrients that are particularly abundant in fruits (Ayaz et al. 2000, Fortalezas et al. 2010, Pallauf et al. 2008). These secondary metabolites are involved in many aspects of plant biological systems: pigmentation, growth and reproduction mechanisms, protection against predators, etc. (Fortalezas et al. 2010, Oliveira et al. 2011, Abbas 2015).

In Morocco, the Arbutus unedo L. remains poorly studied and known from the point of view of nutritional and therapeutic uses in medicine (Bellakhdar 1997, Meziane 2003, Sijelmassi 1993, Ziyyat \& Boussairi 1998). Several scientific studies at the Mediterranean scale have demonstrated the great nutritional value of Arbutus, thanks to its composition in certain nutrients (carbohydrates, vitamins and minerals) and phytonutrients (polyphenols). Although the value of uses of this species in other Mediterranean countries, it remains very limited and undiversified in Morocco (Abbas 2015). The cultivation of this species is restricted as it is not consumed widely but except local population living close to the forests and they are either socially or economically backward. The exploitation of this species remains traditional (Jaradat 1995). Their loss, due to over-exploitation, could jeopardize the socio-economic development of present and future generations. Therefore, the conservation, preservation and sustainable use of these resources remain necessary. Thus, the high sustainable production in this species can contribute to reinforce its consumption as an alternative to the fruits 
available on the market or a source of bioactive compounds for food supplements necessary (Aparicio et al. 2008, Gomes \& Canhoto 2009). Any wise program of production, breeding, and conservation should be based on reliable information about the geographical and ecological distribution, on the one hand and the other, of the variation and genetic structure of the species (Aparicio et al. 2008, Gomes \& Canhoto 2009). At present, no study is done on the characterization of the geographical and ecological distribution potential of the Arbutus in Morocco. Developing and enriching the database with information on the use and geographical distribution of the Arbutus will be at the service of all improvement programs and genetic conservation, both nationally and internationally. In this context, the objective of this work is to describe the distribution and ecological status of natural populations, and to compile available data on the ethnobotanical uses of Arbutus in Morocco in comparison with other studies at the international level.

\section{Material and methods}

In order to describe the distribution and ecology status and the state of conservation of the populations (e.g. dense or clear, natural or planted, etc.) of Arbutus unedo in Morocco, prospecting missions were organized during two companies in 2016 and 2017. For this purpose, we initiated the collection of information on geographic and ecological distribution data from desk research (Aafi et al. 2002) and the use of existing archives at the local, regional and national levels (Forest Management Documents in Morocco). In practice, an informal consultative approach based on interviews with the competent services and facilitators has been adopted for the localization of the natural sites of the Arbutus (case of the services of Water and Forests and the local population including pastors and farmers of the Arbutus). However, we organized several outings during the years of 2016 and 2017 by browsing largely the range of Arbutus unedo in Morocco. Once the sites and populations of Arbutus localized after the prospection stage and their natural origins verified, the harvest was conducted in November 2017. The basic information on the distribution of the species is useful to choose the sampling procedure to use. Seventeen populations in geographically different regions were sampled at eight to twenty individuals per population (Fig. 1).

In terms of ethnobotanical use, we collected as much information as possible (Table 3 ) based on a set of antecedent ethnobotanical studies applied to the national and international strawberry tree (e.g. Favier et al. 1993, Correia et al. Rodriguez et al. 2011). In practice during the survey, we conducted interviews with the local population of the regions visited on the vernacular name, the parts used (leaves, fruit, root, bark), the method of preparation and the therapeutic uses practiced.

\section{Results and discussion}

Distribution and ecological status of the natural populations of the Arbutus tree

The prospecting carried out during the period 2016 and 2017 (unpublished data), and the collection of information from documentary research and the use of existing archives at the local, regional and national levels in Morocco, enabled us to determine the distribution area of the more or less dense natural populations of the Arbutus unedo L. It grows spontaneously in the scrublands of forest and periforest areas belonging to the holm oak, cork oak and high and dense maquis of the mesomediterranean region of the Western Rif, Central Plateau, and the Middle and High Atlas (Aafi et al. 2002). In the light of these data, the natural distribution status of the Arbutus tree in the different ecological regions; namely Northwest, Central Plateau, Pre-Rif and Western Rif, High and Middle Atlas were assessed. Thus, seventeen zones have been identified with areas of natural Arbutus population more or less dense according to the bioclimatic gradient (Table 1, Fig.1). The densest populations in Arbutus are found in the Northwest (Ouezzane case), Pre-Rif (Taounate case) and Western Rif (Chefchaouen case) regions, where the climate is subhumid to humid (Table 2). The density estimate of this forest species was established only by direct observation of strawberry tree individuals in relation to a given area. However, the state of the Arbutus tree in some areas of the North-West (Larache) and the Western Rif (Bab Taza and Ketama cases) is threatened by forest fires in favour of the creation of agricultural land due to the good quality of the climate and soil. The Middle Atlas (case of El Ksiba (Beni-Mellal)) and Central Plateau (case of Ouelmès (Kemisset)) areas, where the climate is subhumid and humid, are characterized by moderately dense natural populations (Table 2). The bioclimatic stages of the semi-arid (Table 2) linked to the Middle (Azilal) and High Atlas (Al Haouz) areas have less dense populations in Arbutus. But it can sometimes be found in the sporadic state of Arbutus trees in the upper limit of forest vegetation, as in the case of the Souss plateau regions (Personal communication with an ecologist from the Faculty of Science of Agadir (Souss). This person is a professor of higher education who carries out scientific research and the activities of educational outings in ecology of more than 25 years). It should 
be noted that all the geographical regions of distribution of the Arbutus are characterized by an average annual temperature and precipitation, respectively, between $12.4^{\circ} \mathrm{C}$ and $18.4^{\circ} \mathrm{C}$ and between 337 and $1115 \mathrm{~mm}$ (Table 2). Its altitudinal range is between $150 \mathrm{~m}$ (Larache) and $1613 \mathrm{~m}$ (Khenifra) (Table 2). The Arbutus tree is widespread on all types of substrates but most often siliceous and calcareous (Aafi et al. 2002). This species prefers fresh, well-drained soils, and when it is in a stand, it indicates the characteristic of good fertility stations (Aafi et al. 2002).

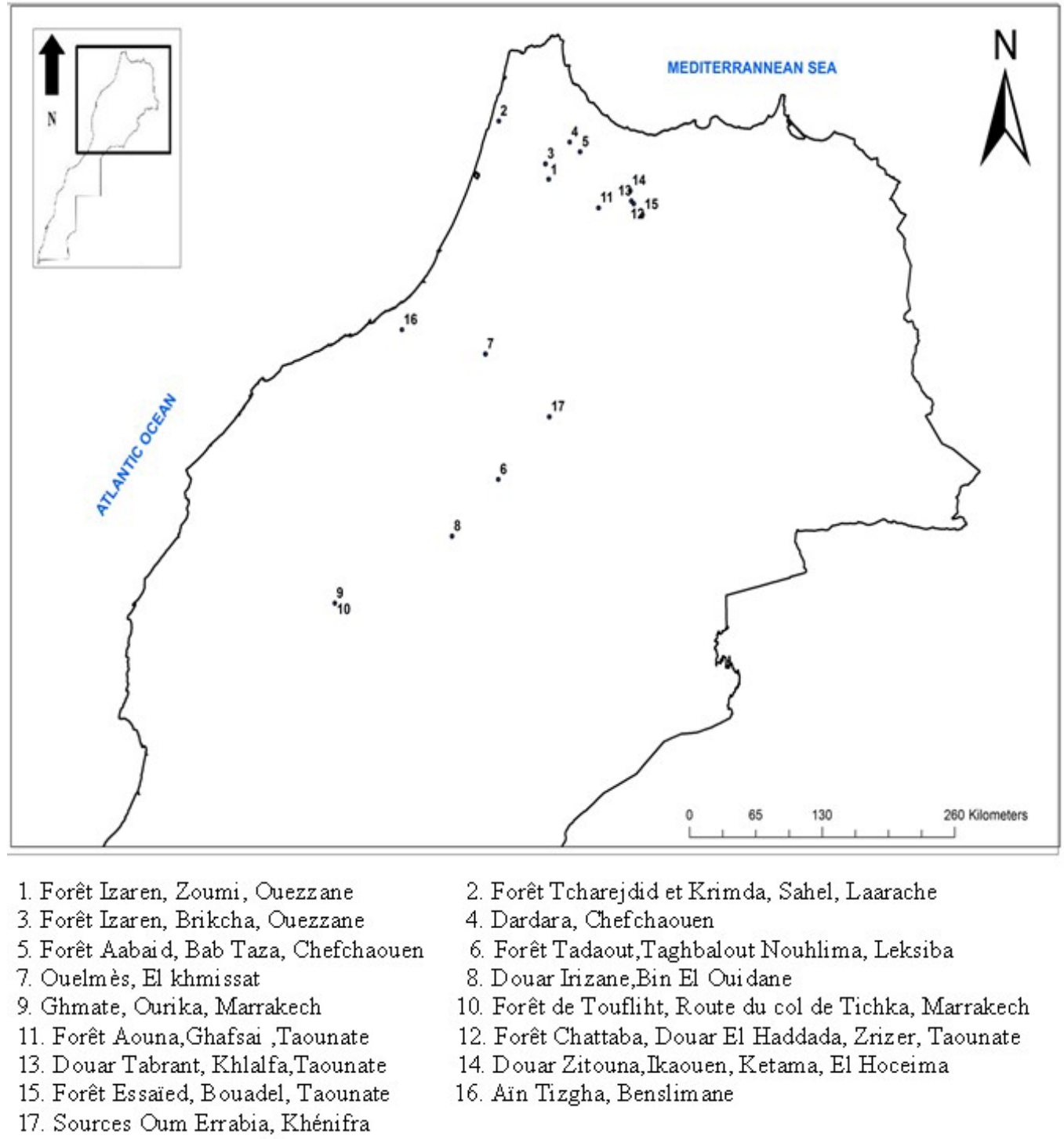

Fig. 1: Location of the different populations with their origins from the Arbutus tree prospected in Morocco.

Surveys of vegetation indicative of the presence of the Arbutus tree, carried out during the survey, revealed a diversity of species that contribute to the individualization of forest and pre-forest ecosystems. Indeed, the forest species that contribute to the individualization of the different types of stands of the Arbutus tree are: Quercus ilex, Quercus suber, Quercus pyrenaica, Pinus halepensis Tetraclinis articulata, Juniperus oxycedrus, Juniperus thurifera. Other species such as Pistacia lentiscus, Cistus (Cistus monspeliensis, Cistus villosus, Cistus ladaniferu), Myrtus communis, Crataequs, Ceratonia siliqua, Olea europaea subsp. europaea var. sylvestris, Chamaerops humils, Eucalyptus globulus, Tamarix aphylla, Daphne gnidium, Urginia maritima, Lavandula sticas, Asphodelus albus, Nerium oleander, Laurus nobilis, Asparagus officinalis and Globularia alypum.

Due to its ecological and phyto-association plasticity, its resistance to mutilation and its great dynamism, it is very present in the daily uses of foresters, farmers and rural populations. 
Table 1. Characteristics of the administrative regions of Arbutus populations prospected and collected in Morocco.

\begin{tabular}{|c|c|c|c|c|c|}
\hline $\begin{array}{l}\text { Popul- } \\
\text { ations }\end{array}$ & $\begin{array}{c}\text { Administrative } \\
\text { regions }\end{array}$ & Provinces & Circles & Caïdats & Communes \\
\hline 1 & \multirow{6}{*}{$\begin{array}{l}\text { Tanger- Tétouan- } \\
\text { AL Hoceima }\end{array}$} & Ouazzane & Mokrisset & Zoumi & Zoumi \\
\hline 3 & & Ouazzane & Mokrisset & Brikcha & Brikcha \\
\hline 2 & & Laarache & $\begin{array}{l}\text { Oued El } \\
\text { Makhazine }\end{array}$ & Khmiss Sahel & Sahel \\
\hline 4 & & Chefchaouen & Bab Taza & Tanaqoub & Dardara \\
\hline 5 & & Chefchaouen & Bab Taza & Béni Ahmed & Bab Taza \\
\hline 14 & & Al Hoceima & Ketama & Ikaouen & Abd Elghaya Souahel \\
\hline 6 & \multirow{3}{*}{$\begin{array}{l}\text { Béni Mellal- } \\
\text { Khénifra }\end{array}$} & Béni Mellal & El Ksiba & Aït Ouirra & Taghbalout Nouhlima \\
\hline 8 & & Azilal & Ouaouizeght & Ouaouizeght & Bin El Ouidane \\
\hline 17 & & Khénifra & Khénifra & Khénifra & Oum Errabia \\
\hline 7 & $\begin{array}{c}\text { Rabat-Salé- } \\
\text { Kénitra }\end{array}$ & Khémisset & Ouelmès & Ouelmès & Ouelmès \\
\hline 9 & \multirow[t]{2}{*}{ Marrakech- Safé } & Al Haouz & Aït Ourir & Ghmate & Ghmate \\
\hline 10 & & Al Haouz & Touama & Tazart & Tazart \\
\hline 11 & \multirow[t]{4}{*}{ Fès-Meknès } & Taounate & Ghafsai & Ourtzag & Ghafsai \\
\hline 12 & & Taounate & Taounate & Bouhouda & Zrizer \\
\hline 13 & & Taounate & Taounate & Bouhouda & Khlalfa \\
\hline 15 & & Taounate & Taounate & Bni Oulid & Bouadel \\
\hline 16 & $\begin{array}{l}\text { Casablanca- } \\
\text { Settat }\end{array}$ & Benslimane & Aïn Tizgha & Ziaïda & Aïn Tizgha \\
\hline
\end{tabular}

Table 2. The geographical and ecological characteristics of the natural populations of the Arbutus tree prospected and collected in Morocco.

\begin{tabular}{|c|l|c|c|c|c|c|l|}
\hline Pop & $\begin{array}{l}\text { Geographic } \\
\text { Region }\end{array}$ & $\begin{array}{c}\text { Latitude } \\
\mathbf{( N )}\end{array}$ & $\begin{array}{c}\text { Longitude } \\
\mathbf{( W )}\end{array}$ & $\begin{array}{c}\text { Altitude } \\
(\mathbf{m})\end{array}$ & $\mathbf{T}\left({ }^{\circ} \mathbf{C}\right)$ & Pr (mm) & $\begin{array}{c}\text { Bioclimatic } \\
\text { zone }\end{array}$ \\
\hline $\mathbf{1}$ & North West & $34^{\circ} 48^{\prime}$ & $5^{\circ} 29^{\prime}$ & 422 & 17,9 & 889 & Sub-Humid \\
\hline $\mathbf{2}$ & North West & $35^{\circ} 15^{\prime}$ & $6^{\circ} 21^{\prime}$ & 150 & 17,9 & 700 & Sub-Humid \\
\hline $\mathbf{3}$ & North West & $34^{\circ} 55^{\prime}$ & $5^{\circ} 31^{\prime}$ & 200 & 18,4 & 883 & Sub-Humid \\
\hline $\mathbf{4}$ & Western Rif & $35^{\circ} 51^{\prime}$ & $5^{\circ} 16^{\prime}$ & 450 & 17,6 & 835 & Sub-Humid \\
\hline $\mathbf{5}$ & Western Rif & $35^{\circ} 11^{\prime}$ & $5^{\circ} 91^{\prime}$ & 745 & 15,3 & 1135 & Humid \\
\hline $\mathbf{1 4}$ & Central Rif & $34^{\circ} 43^{\prime}$ & $4^{\circ} 37^{\prime}$ & 654 & 12.4 & 831 & Sub-Humid \\
\hline $\mathbf{1 1}$ & Pre-Rif & $34^{\circ} 35^{\prime}$ & $4^{\circ} 57^{\prime}$ & 450 & 18,4 & 735 & Sub-Humid \\
\hline $\mathbf{1 2}$ & Pre-Rif & $34^{\circ} 37^{\prime}$ & $4^{\circ} 35^{\prime}$ & 645 & 18,2 & 613 & Sub-Humid \\
\hline $\mathbf{1 3}$ & Pre-Rif & $34^{\circ} 38^{\prime}$ & $4^{\circ} 36^{\prime}$ & 709 & 16,0 & 662 & Sub-Humid \\
\hline $\mathbf{1 5}$ & Pre-Rif & $34^{\circ} 32^{\prime}$ & $4^{\circ} 29^{\prime}$ & 709 & 16,6 & 612 & Sub-Humid \\
\hline $\mathbf{6}$ & Middle Atlas & $32^{\circ} 31^{\prime}$ & $6^{\circ} 11^{\prime}$ & 1338 & 16,4 & 718 & Sub-Humid \\
\hline $\mathbf{8}$ & Middle Atlas & $32^{\circ} 05^{\prime}$ & $6^{\circ} 29^{\prime}$ & 1313 & 17,6 & 490 & Semi-arid \\
\hline $\mathbf{1 7}$ & Middle Atlas & $33^{\circ} 01^{\prime}$ & $5^{\circ} 29^{\prime}$ & 1613 & 13,2 & 702 & Sub-Humid \\
\hline $\mathbf{7}$ & Central Plateau & $33^{\circ} 28^{\prime}$ & $6^{\circ} 91^{\prime}$ & 983 & 13,6 & 756 & Sub-Humid \\
\hline $\mathbf{1 6}$ & Central Plateau & $33^{\circ} 39^{\prime}$ & $7^{\circ} 21^{\prime}$ & 275 & 17,4 & 463 & Semi-arid \\
\hline $\mathbf{9}$ & High Atlas & $31^{\circ} 33^{\prime}$ & $7^{\circ} 42^{\prime}$ & 967 & 17,7 & 337 & Semi-arid \\
\hline $\mathbf{1 0}$ & High Atlas & $31^{\circ} 29^{\prime}$ & $7^{\circ} 24^{\prime}$ & 867 & 18,0 & 360 & Semi-arid \\
\hline
\end{tabular}

Pop: populations; $\mathbf{T}\left({ }^{\circ} \mathrm{C}\right)$ : Average annual temperature in ${ }^{\circ} \mathrm{C} ; \operatorname{Pr}(\mathrm{mm})$ : Average annual precipitation in $\mathrm{mm}$.

\section{Ethnobotanical use of Arbutus unedo L. in Morocco}

Since time immemorial, man has endeavored to exploit nature for his medical and food needs, and during the development of ancient civilizations the exploitation of plants for medicinal use has developed their knowledge and experimentation in this field (Lahsissene et al. 2009, Rhattas et al. 2016). Thus, various studies have been published over the past few decades that have provided information on the vernacular names, the types of 
diseases treated, parts used and the preparation method of the Arbutus tree (Table 3).

The results of previous ethnobotanical studies applied to the Arbutus tree show that leaves are the most commonly used plant parts, followed by the underground part and fruits (Table 3 ). The rest of the plant parts (flowers, stems, seeds, and bark) are used less. The predominance of use of one organ over another in the therapeutic field stems from its concentration in active ingredients. Thus, leaves are the most commonly used because they are a site of photochemical reactions and a reservoir of organic matter that results from them (Bammoui et al. 2015, Cunningham 1996).

In order to facilitate the administration of the active ingredients of each part of the plant, several modes of preparation are used, namely decoction, infusion, powder, fumigation, poultice, maceration. In Morocco, the method of preparation of the leaves and/or roots of the Arbutus tree, in powder or raw form, is decoction, which is administered mainly by mouth (Table 3). The frequent use of decoction can be explained by the extraction of a non-concentrated dose of the active ingredients while reducing the toxic effect of certain compounds.

And according to each organ, the decoction of the Arbutus plant is used in many therapeutic actions (Table 3):

Leaves: Herbal tea made from the leaves of the Arbutus tree has often been used to lower blood pressure, and to protect against colds, diabetes and other respiratory diseases (Meziane 2003, Orch et al. 2015). Other studies (Dallahi 2017, Lahsissene et al. 2009, Rhattas et al. 2016, Sijelmassi 1993) have shown that Arbutus leaves have astringent, diuretic, antiblennorragic, antispasmodic, anti-inflammatory, renal antiseptic properties. These properties are due to the presence of tannin, gallic acid and certain glucosides (case of Arbutoside) (Bizouard \& Favier 1992, Favier et al. 1993).

Fruit: consumption of Arbutus fruits is seasonal and responded in the Western Rif region among the "Jbalas" population (Table 3). Seasonal marketing of fruit remains local and linked to its natural distribution area. They are brought by rural people to city markets or sold by the roadside in small baskets made of palmier nain or reed. Fruit valuation is still timid and limited to beekeeping for the production of Arbutus honey from Jbal Moulay Abdessalam (Chefchaouen region (Table 1)), or to the use for the production of jams and pastries by a "Talassemtane" cooperative located in the Western Rif of Morocco (Rhattas et al. 2016). Concerning the therapeutic effect of the fruits of the Arbutus tree, the population of "Jbalas" considers that taking some fruits in infusion to treat digestive diseases and diarrhea. On the other hand, if taken in excess, the infusion of fruits on fasting has a purgative or intoxicating effect. The prospects propose the enhancement of the ways in which the fruits of this species are used as food supplements.

Root: It is used in the treatment of diabetes, digestive diseases, respiratory diseases, rheumatic diseases, and also has anti-inflammatory and osteoarticular action (Orch et al. 2015, Rhattas et al. 2016, Slimani 2016).

Bark: It is reputed to be astringent, diuretic, hypertensive, anti-diarrheal and treats gastric pain (Lahsissene et al. 2009, Rhattas et al. 2016).

Table 3. Synthetic list of the ethnobotanical uses of the Arbutus tree in the different regions of Morocco.

\begin{tabular}{|l|l|l|l|l|l|l|}
\hline Regions & $\begin{array}{l}\text { Vernacular } \\
\text { name }\end{array}$ & $\begin{array}{l}\text { Used } \\
\text { parts of } \\
\text { the plant }\end{array}$ & $\begin{array}{l}\text { Preparation } \\
\text { method }\end{array}$ & $\begin{array}{l}\text { Route of } \\
\text { adminis- } \\
\text { tration }\end{array}$ & Therapeutic action & References \\
\hline $\begin{array}{l}\text { Regional } \\
\text { Natural Park of } \\
\text { Bouhachem } \\
\text { (Rif of } \\
\text { Morocco); Taza } \\
\text { Province (North } \\
\text { of Morocco) }\end{array}$ & $\begin{array}{l}\text { Bakhenou, } \\
\text { El Matroun; }\end{array}$ & Root & $\begin{array}{l}\text { Decoction } \\
\text { Sasnou }\end{array}$ & Oral & $\begin{array}{l}\text { Treatment of } \\
\text { asthma and } \\
\text { stomach }\end{array}$ & $\begin{array}{l}\text { (Bachar et } \\
\text { al. 2016, } \\
\text { Khabbach } \\
\text { et al. 2012) }\end{array}$ \\
$\begin{array}{l}\text { Oujda Region } \\
\text { Sasnou }\end{array}$ & & Decoction & Oral & $\begin{array}{l}\text { Used in respiratory } \\
\text { tract disorders, as } \\
\text { an anti- } \\
\text { inflammatory and } \\
\text { hyperglycemic } \\
\text { agent }\end{array}$ & $\begin{array}{l}\text { (Meziane } \\
2003, \\
\text { Ziyyat et al. } \\
2002, \\
\text { Bezanguer } \\
\text { et al. 1990) }\end{array}$ \\
& & & & & & \\
\end{tabular}




\begin{tabular}{|c|c|c|c|c|c|c|}
\hline $\begin{array}{l}\text { Talassemtane } \\
\text { National Park } \\
\text { (Occidental Rif } \\
\text { of Morocco) }\end{array}$ & Arbousier & & $\begin{array}{l}\text { Decoction } \\
\text { / Raw }\end{array}$ & Oral & $\begin{array}{l}\text { Used against } \\
\text { hypertension, as an } \\
\text { anti-inflammatory, } \\
\text { and against } \\
\text { rheumatism }\end{array}$ & $\begin{array}{l}\text { (Rhattas et } \\
\text { al. 2016) }\end{array}$ \\
\hline Zerhoun region & $\begin{array}{l}\text { Sasnou, } \\
\text { Bakhnou }\end{array}$ & & $\begin{array}{l}\text { Decoction/ } \\
\text { Infusion }\end{array}$ & Oral & $\begin{array}{l}\text { Treatment of the } \\
\text { Osteo-articular, } \\
\text { metabolic, and } \\
\text { digestive tract }\end{array}$ & $\begin{array}{l}\text { (Slimani } \\
\text { 2016) }\end{array}$ \\
\hline $\begin{array}{l}\text { Izarene region } \\
\text { (North of } \\
\text { Morocco) }\end{array}$ & Sasnou & & Decoction & Oral & $\begin{array}{l}\text { Treatment of high } \\
\text { blood pressure and } \\
\text { diabetes }\end{array}$ & $\begin{array}{l}\text { (Orch et al. } \\
2015, \\
\text { Abdalla et } \\
\text { al. 1994) }\end{array}$ \\
\hline $\begin{array}{l}\text { Achach Forest } \\
\text { (Central } \\
\text { Plateau of } \\
\text { Morocco) }\end{array}$ & $\begin{array}{l}\text { Lenj, } \\
\text { Bakhenû, } \\
\text { Arbousier }\end{array}$ & & Decoction & Oral & $\begin{array}{l}\text { Used for high blood } \\
\text { pressure and liver } \\
\text { aches }\end{array}$ & $\begin{array}{l}\text { (Kahouadji } \\
\text { 1995, } \\
\text { Bammi et al. } \\
\text { 2002) }\end{array}$ \\
\hline $\begin{array}{l}\text { Izarène region } \\
\text { (North of } \\
\text { Morocco) }\end{array}$ & Sasnou & Leaves & Decoction & Oral & $\begin{array}{l}\text { Treatment of high } \\
\text { blood pressure and } \\
\text { diabetes }\end{array}$ & $\begin{array}{l}\text { (Orch et al. } \\
2015)\end{array}$ \\
\hline $\begin{array}{l}\text { Zaër region } \\
\text { (Occidental } \\
\text { Morocco) }\end{array}$ & $\begin{array}{l}\text { Sasnou, } \\
\text { Arbousier }\end{array}$ & & Decoction & Oral & $\begin{array}{l}\text { Used against } \\
\text { urinary stones }\end{array}$ & $\begin{array}{l}\text { (Lahsissene } \\
\text { et al. 2009) }\end{array}$ \\
\hline Oujda Region & Sasnou & & Decoction & Oral & $\begin{array}{l}\text { Diuretic effect, } \\
\text { urinary antiseptic }\end{array}$ & $\begin{array}{l}\text { (Meziane } \\
2003, \\
\text { Aarons et } \\
\text { al.1977, } \\
\text { Abadome } \\
\text { 1998) }\end{array}$ \\
\hline $\begin{array}{l}\text { Sibe of } \\
\text { Kharrouba } \\
\text { (Central } \\
\text { Plateau of } \\
\text { Morocco) }\end{array}$ & Sasnou & & Decoction & Oral & $\begin{array}{l}\text { Anti-inflammatory, } \\
\text { antispasmodic and } \\
\text { anti-blennorrhagic } \\
\text { Depurative, } \\
\text { antiseptic, } \\
\text { astringent, anti- } \\
\text { inflammatory, and } \\
\text { diuretic effect }\end{array}$ & $\begin{array}{l}\text { (Dallahi } \\
2017, \\
\text { Sijelmassi } \\
1993 \text { ) }\end{array}$ \\
\hline $\begin{array}{l}\text { (Occidental Rif) } \\
\text { of Morocco) }\end{array}$ & Arbousier & Bark & $\begin{array}{l}\text { Decoction } \\
\text { / Raw }\end{array}$ & Oral & Diuretic effect & $\begin{array}{l}\text { (Rhattas et } \\
\text { al. 2016) }\end{array}$ \\
\hline Zaër Region & Sasnou & & Decoction & Oral & $\begin{array}{l}\text { Recommended for } \\
\text { gastric pain }\end{array}$ & $\begin{array}{l}\text { (Lahsissene } \\
\text { et al. 2009) }\end{array}$ \\
\hline Oujda Region & Sasnou & & Decoction & Oral & $\begin{array}{l}\text { Diuretic and } \\
\text { hypertensive effect }\end{array}$ & $\begin{array}{l}\text { (Meziane } \\
2003, \\
\text { Agoumi } \\
\text { 1983, Aït } \\
\text { Igri et al. } \\
\text { 1990) }\end{array}$ \\
\hline $\begin{array}{l}\text { Central Plateau } \\
\text { of Morocco }\end{array}$ & Sasnou & & Decoction & Oral & $\begin{array}{l}\text { Depurative, } \\
\text { antiseptic, } \\
\text { astringent, anti- } \\
\text { inflammatory, and } \\
\text { diuretic effect }\end{array}$ & $\begin{array}{l}\text { (Dallahi } \\
2017, \\
\text { Sijelmassi } \\
\text { 1993) } \\
\end{array}$ \\
\hline
\end{tabular}




\begin{tabular}{|c|c|c|c|c|c|c|}
\hline $\begin{array}{l}\text { Occidental Rif } \\
\text { of Morocco }\end{array}$ & Sasnou & Fruit & Gross & & $\begin{array}{l}\text { Jam and pastry } \\
\text { making }\end{array}$ & $\begin{array}{l}\text { (Rhattas et } \\
\text { al. 2016, } \\
\text { Orch et al. } \\
\text { 2017) }\end{array}$ \\
\hline $\begin{array}{l}\text { Rabat, Zaërs, } \\
\text { Chaouïa; } \\
\text { Essaouira } \\
\text { Region }\end{array}$ & $\begin{array}{l}\text { Lenj, } \\
\text { Bakhenû; } \\
\text { Azoubar }\end{array}$ & & Raw & Oral & $\begin{array}{l}\text { Treatment of } \\
\text { digestive diseases }\end{array}$ & $\begin{array}{l}\text { (Bammi et } \\
\text { al. 2002, } \\
\text { Mehdioui et } \\
\text { al. 2007) }\end{array}$ \\
\hline $\begin{array}{l}\text { Jbala, } \\
\text { Talambot } \\
\text { And Ghomara }\end{array}$ & $\begin{array}{l}\text { Metrûn, } \\
\text { Unnis (for } \\
\text { the } \\
\text { fruit), Qâtil } \\
\text { abihi, Bojj, } \\
\text { Jînâ,Qatlab, } \\
\text { Asir Ddob }\end{array}$ & & Raw & Oral & $\begin{array}{l}\text { Taking a few fruits } \\
\text { stops diarrhea, but } \\
\text { in excess, it would } \\
\text { be purgative }\end{array}$ & $\begin{array}{l}\text { (Bellakhder } \\
\text { 1997) }\end{array}$ \\
\hline $\begin{array}{l}\text { Oujda Region; } \\
\text { (Occidental Rif } \\
\text { of Morocco) }\end{array}$ & Sasnou & & Raw & Oral & $\begin{array}{l}\text { Depurative and anti- } \\
\text { diarrheal effect }\end{array}$ & $\begin{array}{l}\text { Rhattas et } \\
\text { al. } 2016 \text {, } \\
\text { Orch et al. } \\
2017 \text {, } \\
\text { Meziane } \\
2003 \text {, } \\
\text { Akhmisse } \\
\text { 1991) }\end{array}$ \\
\hline $\begin{array}{l}\text { Moulay } \\
\text { Abdessalam } \\
\text { Ben Mchich }\end{array}$ & $\begin{array}{l}\text { Sasnu, } \\
\text { Boukhanou }\end{array}$ & & Raw & & $\begin{array}{l}\text { Production of "Jbal } \\
\text { Moulay } \\
\text { Abdessalam" } \\
\text { Arbutus honey from } \\
\text { fruit }\end{array}$ & $\begin{array}{l}\text { (MAPM } \\
2014)\end{array}$ \\
\hline
\end{tabular}

\section{Use of the Arbutus tree in other countries}

The distillation of the Arbutus fruit and their marketing dates back to 1815 in Corsica in the Bastia region. In Italy, Fruit liqueur is marketed by small companies (Bizouard \& Favier 1992, Favier et al. 1993). Over time, the value of the use of fruit is becoming more and more progressive for the production of alcoholic beverages due to its high fermentable sugar content. In Portugal, the most important activity associated with the fruit of this species is the production of "Medronho" wine liqueurs and brandies (Correia \& Oliveira 2002). The wine of the Arbutus fruit contains 40 to $60 \%$ alcohol (Doukani 2015, Haciseferogullari \& Özcan 2007). Due to its high pectin content, Arbutus fruit is also used in the production of jellies, jams, marmalades, yoghurts and other traditional desserts (Pallauf 2008, Pawlowska et al. 2006, Silva-E-Alarcão et al. 2001, Simonetti et al. 2008, Tardio et al. 2002). It is also incorporated in cereal and meat products because of carbohydrates accumulated during the immature and mature stages of the fruit (Silva-E-Alarcão et al. 2001). Its sugar content is about $0.47 \mathrm{~g} / \mathrm{g}$ dry base in sachharose $(87.7 \pm 0.6 \mathrm{~g}$ per $\mathrm{kg}$ of dried fruit) and fructose (208 $\pm 2 \mathrm{~g}$ per $\mathrm{kg}$ of dried fruit) (Silva-EAlarcão et al. 2001). Dry fruit is used to make tea, flavors and colors in the industry (Demirosy et al. 2007). In the last decade, several food products have been processed and marketed in powder form, but scientific studies on this subject for Arbutus fruit remain insufficient despite their importance in the field of engineering (Murietta et al. 2012). Studies on the properties of whole fruit tablets are very limited. However, an Italian study shows that Sardinian bitter honey, which contains a high proportion of strawberry nectar, has important antibacterial and antiviral properties (Floris \& Prota 1989). Bees do not collect Arbutus pollen, which is one of the primary sources of food for the fall generation of the land bumblebee (Bombus terrestris) (Rasmont 2005). In addition, the Arbutus fruit can therefore be considered as a food supplement since it is rich in nutrients such as minerals (calcium, phosphorus, potassium) and vitamins (vitamin C) (Devla et al. 2011, Ziyyat \& Boussairi 1998). Also, the Arbutus fruit is a good source of antioxidants (Tawaha et al. 2007) including carotenoids, anthocyanins and elagic acid. Proanthocyanides represent more than $80 \%$ of total fruit flavonoids (Ayaz et al. 2000, SilvaE-Alarcão et al. 2001, Tawaha et al. 2007). In this regard, Rodriguez et al (2011) reported that the high antioxidant potential of Arbutus is attributed to the activity of various bioactive components including vitamin C. In this respect, the antioxidant power of these berries has been found to be one of the highest among the fruits studied by Allane and Benamara 
(2010).

The Arbutus fruit is classified as a medicinal (Bammi \& Douira 2002, Rahman 2007). Several therapeutic values are attributed to this fruit, which explains its ancient use in traditional and popular medicine (Mariotto et al. 2008). These are: gastrointestinal disorders (Cornara et al. 2009), dermatological problems as antiseptics (Pallauf et al. 2008), cardiovascular application (Leonti 2009), urological problems (El Hilaly et al. 2003), and antimicrobial activity (Kivçak et al. 2001). Heinrich et al. (2005) studied extracts of this fruit species on different parameters such as enzymatic inhibition tests and inhibition of cytokine induced cell activation. This proves the ability of these fruits to inhibit DNA synthesis and cell proliferation. When used in low concentrations, Arbutus fruit does not cause any adverse effects; the fruit could even have a beneficial effect. The fruit of the strawberry tree is therefore edible, provided that reasonable quantities are ingested. On the other hand, for subjects with oxalic lithiasis, Arbutus fruit with its high amount of calcium oxalate, or oxalic acid, should eventually be discouraged (Bizouard \& Favier 1992).

Flowering seems interesting for beekeepers and does not have the defect of some Ericaceae (in particular Andromeda polifolia) whose flowers make bees produce toxic honey (Bizouard \& Favier 1992, Favier et al. 1993). But it must be recognized that it favors the secretion of wax rather than honey in bees. In any case, the flowers of the Arbutus tree produce abundant nectar whose main interest is to constitute an early food source for bees, which use it among other things to start the brood.

The strawberry tree's wood is relatively easy to work with, and the stump is used to make pipes appreciated by professionals. Carbonization provides excellent charcoal in Greece, (Bizouard \& Favier 1992, Favier et al.1993) Bark is still used for tanning leather (Bizouard \& Favier 1992, Favier et al.1993).

\section{Conclusion}

The survey of the Arbutus tree's natural distribution areas in Morocco has shown that the species grows in semi-arid bioclimates with hot to cool per-humid variants in the thermo-mediterranean and mesomediterranean on limestone and siliceous soils. It is mainly associated with Quercus ilex and sometimes with Pinus halepensis and Tetraclinis articulata. It is located in different biogeographical regions that could contribute to such high genetic diversity. It is economically very important to study and determine the genetic and ecological properties of the Arbutus tree for medicinal and ornamental purposes.
The related literature is generally in line with the medicinal use of the plant by Moroccan inhabitants especially for the treatment of diabetes, digestive diseases, respiratory diseases, rheumatic diseases, anti-inflammatory, osteo-articular, hypertensive, and diarrheal diseases. On the other hand, the consumption and industrial valuation of Arbutus fruits remain very limited in Morocco compared to those at the international level. It is imperative to raise awareness among the local population and enclaved town of the knowledge for the valorization of the fruit of this species, how to develop the marketing, the conservation and the transformation of fruits and byproducts, and the production of new medicines and wellness products.

\section{Declarations \\ List of abbreviations: Not applicable.}

Ethics approval and consent to participate: All participants provided Prior Informed Consent.

Consent for publication: Not applicable.

Availability of data and materials: Not applicable.

Competing interests: There are no financial andnon-financial competing interests regarding this work.

Funding: Not applicable.

Authors' contributions: Rahima Faida prepared and analyzed data of the manuscript. This study is part of a doctoral research project. The corresponding author (Nadya Wahid) conceptualized the research idea, contributed to analyze the data and improved the quality of this manuscript. Jamal Aabdousse contributed to prospection and exploration of Arbutus sites. Abdelali Boulli and Said Bouda contributed to the realization of this work.

\section{Acknowledgements}

This study is part of a doctoral research. We would like to thank the Dean of the Faculty of Sciences and Techniques of Beni Mellal for the transport facilities; granted for carrying out field trips and surveys of Arbutus natural distribution areas in Morocco.

\section{Literature cited}

Aafi A, Taleb MS, Fechtal M. 2002. Espèces remarquables de la flore du Maroc. MCEF, Rabat, Maroc. 
Aarons DH, Rossi GV, Orzechowski RF. 1997. Cardiovascular actions of three harmala alcaloides: harmine, harmaline and harmol. Journal of Pharmaceutical Sciences 66:1244-1248.

Abadome F. 1998. Contribution à l'étude du traitement par la vitamine $\mathrm{K} 1$ des moutons intoxiqués par Ferula communis et essais de mise à profit de sa toxicité comme raticide, INA Hassan II, Rabat, Maroc.

Abbas A. 2015.Caractérisation physico-chimique du fruit de l'arbousier (Arbutus unedo L.) du nord Algérienne et de la datte (Mech-Degla), Université M'Hamed Bougara- Boumerdes, Boumerdes, Algérie.

Abdalla S, Abu-Zarga M, Sabri M. 1994. Effects of the flavones luteolin, isolated from Colchicum richii on guinea-pig isolated smooth muscle and heart and on blood pressure and blood flow. Phythoterapy Research 8:265-270.

Agoumi S. 1983. Les plantes médicinales à usage anthelminthique dans la province de Fès, Faculté de Médecine et de Pharmacie, Rabat, Maroc.

Aït Igri M, Holeman M, II Idrissi A. 1990. Contribution à l'étude chimique des huiles essentielles des rameaux et du bois de Tetraclinis articulata. Plantes Médicinales et Phytotherapie 24:36-43.

Akhmisse M. 1991. Histoire de la médecine au Maroc (des origines au protectorat), (Ed) Imprimeries Eddar El Beida, Casablanca, Maroc.

Allane T, Benamara S. 2010. Antioxydant activities of some common and wild fruits from Algeria. Phytotherapie 8: 171-175.

Aparicio A, Albaladejo R.G, Olalla-Tarraga M.A, Carrillo L.F, Rodriguez M.A. 2008. Dispersal potentials determine responses of woody plant species richness to environmental factors in fragmented Mediterranean landscapes. Forest Ecology and Management 255: 2894-2906.

Ayaz F, Kucukislamoglu A, Reunanen M. 2000. Sugar, Non-volatile and phenolic Acids Composition of Strawberry Tree (Arbutus unedo L.var.ellipsodiea) Fruits. Journal of Food Composition and Analysis 13:171-177.

Bachar M, Zidane L, Rochdi A. 2016. Ethnomedicinal and traditional Phytotherapy of plants used in Bouhachem Natural Regional Park (Rif of Morocco). Journal of Materials and Environmental Science 11: 4175-4204.

Bammi J, Douira A. 2002. Les plantes médicinales dans la forêt de l'Achach (Plateau Central du Maroc). Acta Botánica Malacitana 27 :131-145.

Bammoui M, Daoudi A, Slimani I. 2015. Valorisation du lentisque Pistacia lentiscus L.: Étude ethnobotanique, Screening phytochimique et pouvoir antibactérien. Journal of Applied Biosciences 86:7966-7975.

Bellakhdar J. 1997. La pharmacopée marocaine traditionnelle: Médecine arabe ancienne et savoirs populaires, (Ed) Ibis Press, Saint- Etienne, France.
Bézanger-beauquesne L, Pinkas M, Torck M. 1990. Plantes médicinales des régions tempérées, $(\mathrm{Ed})$ Maloine, Paris, France.

Bizouard P, Favier JC. 1992. Contribution à l'étude de la valeur nutritive de quelques plantes naturellement abondantes en Corse. Corse Historique 8:1-14.

Boubekri Ch. 2014. Etude de l'activité antioxydante des polyphénols extraits de Solanum melongena par des techniques électrochimiques, Université Mohamed Khider, Biskra, Algérie.

Celikel G, Demirsoy L, Demirsoy H. 2008. The strawberry tree (Arbutus unedo L.) selection in Turkey.Scientia Horticulture 118:115-119.

Cornara L, la Rocca A, Marsili S. 2009. Traditional uses of plants in the Eastern Riviera (Liguria, Italy). Journal of Ethnopharmacology 125: 16-30.

Correia AV, Oliveira AC. 2002. Principais espécies florestais com interesse para Portugal : zonas de influencia Mediterraânica, (2 ${ }^{\text {éme }}$ Ed) Direcçao Geral dasFlorestas, Lisboa, Portugal.

Cunningham AB. 1996. Peuples, parc et plantes: Recommandations pour les zones à usages multiples et les alternatives de développement autour du parc Naturel de Bwindi Impénétrable, Ouganda, Paris. Peuples et Plantes 4 :33-66.

Dallahi Y. 2017. Apport de la télédétection spatiale pour l'étude écologique, phytosocio-logique et cartographique de la Tetraclinaie du Site d'Intérêt Biologique et Ecologique (SIBE) de Kharouba (Plateau Central), Faculté des Sciences Mohammed $\checkmark$, Agdal, Rabat, Maroc.

Demirosy H, Demirsoy L, Celikel G. 2007. Effects of Dried on some properties of Strawberry Tree Fruits. Asian Journal of Chemistry 19: 1777-1782.

Devla MN, Acharya SR, Acharya NS. 2011. Dietary supplements: A legal status in India and in foreign countries. International Journal of Pharmacy and Pharmaceutical Sciences 3: 7-12.

Doukani K, Tabak S. 2015. Profil physicochimique du fruit "Lendj" (Arbutus unedo L.). B-Sciences Agronomiques et Biologiques 12:53- 66.

El-Hilaly J, Hamammouchi M, Lyoussi B. 2003. Ethnobotanical studies and economic evaluation of medicinal plants in Taounate province (Northen Morocco). Journal of Ethnopharmacology 86: 149158.

Favier JC, Ireland-Ripert J, Laussucq C. 1993. Répertoire général des aliments: Table de composition des fruits exotiques, fruits de cueillette d'Afrique, INRA, ORSTOM, Marseille, France.

Fiorentino A, Castaldi S, D'Abrosca B. 2007. Polyphenols from the hydroalcoholic extract of Arbutus unedo living in mono specific Mediterranean woodland. Biochemical Systematics and Ecology 35:809-811.

Floris F, Prota R.1989. Sul miele amaro di Sardegna. Apicoltore Moderno 80:55-67.

Floris I, Lentini A, Prota R. 1992. Flora of apicultural interest in Sardinia: Potantial honey yield of Arbutus unedo in northern Sardinia, Stato Attuale e Sviluppo 
Della Ricerca in Apicoltura Atti Convegno. Journal of Apicultural Research 25:189-200.

Fortalezas S, Tavares L, Pimpão R, Tyagi M, Pontes V, Gordon A, McDougall Mc SD, Ricardo B, Ferreira' Santos CN. 2010. Antioxidant Properties and Neuroprotective Capacity of Strawberry Tree Fruit (Arbutus unedo). Nutrients 2: 214-229.

Gomes F, Canhoto J.M. 2009. Micropropagation of strawberry tree (Arbutus unedo L.) from adult plants. In Vitro Cellular \& Developmental Biology -Plant. 45:72-82.

Hacıseferoğulları H, Özcan M. 2007. The strawberry tree (Arbutus unedo L.) fruits: Chemical composition, physical properties and mineral contents. Journal of Food Engineer 44: 307-315.

Heinrich V, Leung A, Evans E. 2005. Nanotomicroscale mechanical switches and fuses mediate adhesive contacts between leukocytes and the endothelium. Journal of Chemical Information and Modeling $45: 1482-1490$.

Jaradat A.A. 1995. The dynamics of a core collection. In: Hodgkin $\mathrm{T}$, et al. (Eds.), Core Collections of Plant Genetic Resources. John Wiley and Sons, pp. 179-186.

Kahouadji MS. 1995. Contribution á une étude ethnobotanique des plantes médicinales dans le Maroc Oriental, Faculté des Sciences Mohammed I, Oujda, Maroc.

Khabbach A, Libiad M, Ennabili A. 2012. Medicinal and cosmetic use of plants from the province of Taza, Northern Morocco. Boletín Latino americano y del Caribe de Plantas Medicinales y Aromáticas 11:46-60.

Kivçak B, Mert T, Denizci A. 2001. Antimicrobial activity of Arbutus unedo $L$. Journal of Pharmaceutical Sciences 26:125-128.

Konstantinidis P, Tsiourlis G, Xofis P. 2006. Effect of fire season, aspect and pré-fire plant size on the growth of Arbutus unedo L. (strawberry tree) resprouts. Forest Ecology and Management 225: 359-367.

Krussmann G. 1982. Pocket Guide to Choosing Woody Ornamentals, Timber Press, Beaverton, Oregon.

Lahsissene H, Kahouadji A, Tijane M. 2009. Catalogue des Plantes Médicinales Utilisées dans la Région De Zaër (Maroc Occidental). Revue de Botanique 186:26-52.

Leonti M, Casu L, Sanna F. 2009. A comparaison of medicinal plant use in Sardinia and Sicily-De Materia Medica revivisited. Journal of Ethnopharmacology 121:255-267.

Males Z, Plazibat M, Vundac VB. 2006. Qualitative and quantitative analysis of flavonoids of the strawberry tree (Arbutus unedoL.). Acta Pharmaceutica 56:245-250.

MAPM, 2014. Produits du terroir du Maroc, (Ed) Catalogue National, Direction de Développement des Filières de Production, Ministère de l'Agriculture et de la Pêche Maritime Rabat, Maroc.
Mariotto S, Esposito E, Di Paola R. 2008. Protective effect of Arbutus unedo aqueous extract in carrageenan-induced lung inflammation in mice. Pharmacological Research 57:110-124.

Mehdioui R, Kahouadji A. 2007. Etude ethnobotanique auprès de la population riveraine de la forêt d'Amsittène: cas de la Commune d'Imi n'Tlit (Province d'Essaouira). Bulletin de l'Institut Scientifique Rabat 29:11-20.

Meziane M. 2003. Origines de la médecine traditionnelle marocaine: Enquête de terrain dans la région d'Oujda, Faculté de Pharmacie, Nantes, France.

Murrieta-Pazos I, Gaiani C, Galet L. 2012. Food pozders: surface and form characterization revisited . Journal of Food Engineering 112 1-21.

Oliveira I, Baptista P, Malheiro R. 2011. Influence of strawberry tree (Arbutus unedo L.) fruit ripening stage on chemical composition and antioxidant activity. Food Research International 44:1401-1407.

Oliveira I, Coelho V, Baltasar R. 2009. Scavenging capacity of strawberry tree (Arbutus unedo L.) leaves on free radicals. Food Chemical Toxicology 47:15071511.

Orch H, Douira A, Zidane L. 2015. Étude ethnobotanique des plantes médicinales utilisées dans le traitement du diabète, et des maladies cardiaques dans la région d'lzarène (Nord du Maroc). Journal of Applied Biosciences 86: 79407956.

Orch H, Douira A, Zidane L. 2017. Ethnobotanical study of the plants used in the treatment of the digestive diseases by the riverine population of the forest of izarène. International Journal of Recent Scientific Research 1:15213-15220.

Pallauf K, Rivas-Gonzalo JC, Castilli MD. 2008. Characterization of the antioxidant composition of strawberry tree (Arbutus unedo L.) fruits. Journal of Food Composition and Analysis 21:273-281.

Pawlowska AM, De Leo M, Baraca A. 2006. Phenolics of Arbutus unedoL. (Ericaceae) fruits: identification of anthocyanins and gallic acid derivatives. Journal of Agriculture and Food Chemistry 5426:10234-10238.

Pedro J. 1994. Carta da distribuição de figueira e medronheiro - Notícia Explicativa, Ministério do Ambiente e RecursosNaturais, Direcção Geral do Ambiente, Lisboa, Portugal, p. 34.

Rahman M. 2007. Allicin qnd other functional active components in garlic: Health benefits qnd bioavailability. International Journal of Food Properties 10: 245-268.

Rasmont P. 2005. Analysis of pollen and nectar of Arbutus unedo as a food source for Bombus terrestris (Hymenoptera: Apidae). Journal of Economic Entomology 98: 656-663.

Rhattas M, Douira A, Zidane L. 2016. Étude ethnobotanique des plantes médicinales dans le Parc National de Talassemtane (Rif occidental du Maroc). Journal of Applied Biosciences 97:91879211. 
Rodriga de Sà O. 2010. Caracterizaçäo Morfologica, Molecular e Quimica de Arbutus unedo L. com vista à selecçäo de genotipos de superior qualidade, Instituto Plitécnico, Escola Superior Agräria de Bragança, Espagne.

Rodriguez-Ruiz BM, Morales P, Fernández-Ruiz V. 2011. Valorization of wild strawberry-tree fruits (Arbutus unedo L.) through nutritional assessment and natural production data. Food Research International 44:1244-1253.

Seidemann J. 1995. Knowledge of little-known exotic fruits: Strawberry tree (Arbutus unedo L.). Deutsche Lebensmittel-Rundschau 91:110-113.

SijelmassiA. 1993. Les plantes médicinales de Maroc, (3 ${ }^{\text {ème }}$ Ed) Fennec, Casablanca, Maroc.

Silva-E-Alarcão M, Simonetti MS, Damianim F. 2001.The Arbutus Berry: Studies on its color and chemical characteristics at two mature stages. Journal of Food Composition and Analysis 14:27-35.

Simonetti M, Damiani V, Gabrielli L. 2008. Characterization of triacylglycerols in Arbutus unedo L. seeds. Italian Journal of Food Science 20:49-56.

Slimani I, Najem M, Belaidi R. 2016. Étude ethnobotanique des plantes médicinales utilisées dans la région de Zerhoun (Maroc). International Journal of Innovation and Applied Studies 15:846863.

Soro A, Paxto RJ. 1999. Strawberry tree: a significant source of nectar around the Mediterranean basin. Bee World 80:140-144.

Tardio J, Pascual H, Morales R. 2002. Alimentos silvestres de Madrid: Guia de plantas y setas de uso alimenatrio tradicional en la Comunidad de Madrid, La Libreria (Ed), Madrid, Espagne.

Tawaha K, Alali F, Gharaibeh M. 2007. Antioxidant activity and total phenolic content of selected Jordanian plant species. Food Chemistry 104:13721378.

Torres JA, Valle F, Pinto C. 2002. Arbutus unedocommunities in southen Iberian Peninsula Mountains. Plant Ecology 160:207-223.

Ziyyat A, Boussairi E. 1998. Cardiovascular effects of Arbutus unedoL. in spontaneously hypertensive rats. Phytotherapy Research 12:110-113.

Ziyyat A, Mekhfi H, Bnouham M. 2002. Arbutus unedo induces endothelium-dependent relaxation of the isolated rat aorta. Phytotherapy Research 16:572-575. 